\title{
Bovine Leukemia Perspectives and its Impact on Dairy
}

\author{
Cristina Úsuga Monroy*, José Julián Echeverri Zuluaga and Albeiro López Herrera \\ Department of Animal Production, Faculty of Agricultural Sciences, National University of Colombia at Medellín, Colombia
}

Submission: June 20, 2018; Published: July 24, 2018

*Corresponding author: Cristina Úsuga Monroy, Department of Animal Production, Faculty of Agricultural Sciences, National University of Colombia at Medellín, Colombia, Tel: (57) 3137062484; Fax (57-4) 4309025; Email: cusugam@unal.edu.co

\begin{abstract}
Livestock production is affected by several diseases caused by microorganisms such as viruses, bacteria or protozoa that reduce the efficiency and profitability of livestock enterprises by causing economic losses. The enzootic bovine leukemia (EBL) is a disease that affects cattle and especially those dedicated to milk production, is caused by the bovine leukemia virus (BLV). The EBL is one of the diseases of mandatory declaration for terrestrial animals according to the World Organization for Animal Health. The importance of this disease in the productive systems is due to the fact that currently there is no vaccine or treatment and therefore the eradication and control of this virus is based on early diagnosis. The use of different molecular or serological methodologies, not only allow to identify the prevalence in a herd, but also to understand more about the biology of the virus and to design strategies that allow to control the dispersion of the same through management practices that will be reflected in the increase of productive or reproductive parameters of the herd.
\end{abstract}

Keywords: Bovine leukemia; Diagnosis; Milk production; Immune system; Terrestrial animals; Animal Health; Lymphocytes; Etiology; Enzootic Dairy farms; Cattle; Streptococcus; Pathogens; Livestock; Dairy Herds

Abbreviations: EBL: Enzootic Bovine Leukemia; BLV: Bovine Leukosis Virus; BIV: Bovine Immunodeficiency Virus; OIE: Organization of Animal Health; BoLA: Bovine Leukocyte Antigen;

\section{Introduction}

Enzootic bovine leukemia (EBL) is a disease of viral origin caused by infection with bovine leukosis virus (BLV), characterized by affecting the immune system of cattle, specifically B lymphocytes. Bovines are usually clinically healthy and It is so much more difficult to control the disease. The EBL was reported for the first time in 1871 in Germany by Leisering, who described yellowish nodules in the spleen of the cattle which he called leukemia [1]. In-apparent infection is often accompanied (30-70\%) by an increase in white blood cell count called persistent lymphocytosis. On the other hand, between 0.1 and $10 \%$ of cattle with more than 3 years of infection can present the tumor form of the disease or lymphosarcoma [2], this is characterized by the lack of control over the cell cycle of the lymphoid line (lymphocytes B). It has been shown that the herds infected with BLV had a lower milk production between 2.5 to $7 \%$ compared to the average production of the herd $[3,4]$ and an increase in the rate of selective losses, as well as greater susceptibility to other diseases of infectious etiology such as mastitis [5], diarrhea and pneumonia [3].

\section{Distribution}

The BLV is widely distributed in the world, probably migrated from Europe to America through infected cattle. Some countries in Europe are free while others are in the process of eradication [6]. In countries like the United States of America where milk production plays an important role in the economy, a seroprevalence of $83.9 \%$ can be found ( 452 of 534 dairy farms sampled) according to the report presented by the Department of Agriculture (USDA) and the National Animal Health Monitoring System (NAHMS) in 2007 [7]. It is considered that in America the disease is enzootic; the molecular prevalence for BLV in Colombia is $44 \%$ of infection in Holstein cows [8], while other countries in South America have lower molecular prevalence such as Chile $27.9 \%$, Bolivia $30.7 \%$ or Peru $42.3 \%$. Countries such as Paraguay and Argentina have higher prevalence than those found in Colombia (54.7\% and $77.4 \%$ respectively) [9].

\section{Transmission}

The EBL is transmitted through two routes, horizontally through direct contact between an infected animal and an uninfected animal, the reuse of needles for vaccination processes, gloves during palpation [10] or dehorning [11] they help the spread of the virus. The virus can also be transmitted vertically from mother to calf within the uterus, which can be up to $26 \%$. Colostrum is another vehicle for the BLV [12], in which the cells may be infected especially if the mothers are co-infected with the bovine immunodeficiency virus (BIV) [13]. 


\section{Diagnosis}

Because there is no vaccine or treatment for bovine leukemia, the eradication and control of this disease is based on early diagnosis, separation and differential management of infected animals. Because of this, the specificity and sensitivity of the diagnostic test used is a critical point [14]. The samples of blood, milk, colostrum and semen have been used for the identification of BLV through serological and molecular techniques. Serological tests (AGID and ELISA) are the tests currently recommended by the Organization of Animal Health (OIE) for the diagnosis of infection. However, the methodologies that directly detect the virus are very important, such as PCR. It has been reported that PCR is a highly sensitive methodology for the direct diagnosis of BLV [15-17].

\section{Productive Impact}

EBL generates costs for secondary treatments, repetition of vaccine doses [18] and indirect losses due to reproductive failures associated with secondary infections such as metritis [3] and reproductive parameters are affected so that infected cows have a greater interval between births and services by conception. Milk production can be reduced up to $7.67 \%$ with respect to the herd [19] and the compositional quality of milk is also affected as infected cows produce less amount of protein [20]. On the other hand, the somatic cell score is higher in infected cows because the BLV infection increases the susceptibility to other pathogens such as bacteria of the genus Streptococcus, which have been found more frequently (35.9\%) in cows positive to BLV with respect to cows free of infection [21].

\section{Discussion}

\section{Molecular and Serological Prevalence of BLV in Antioquia, Colombia}

The evaluation of 1000 Holstein cattle of specialized dairy herds in the department of Antioquia has allowed to establish a molecular prevalence of $47.6 \%$; while the serological prevalence was $54.6 \%$ [22]. The prevalence of EBL in the Antioquia region has been increasing during the last years, since for 1984 the Andean region presented seroprevalences of $29.9 \%$ [23] and today it is more than $50 \%$. The place of origin of the animals is herds (X2=777.6420 $\mathrm{P}<0.0001)$, municipalities (X2=500.5000 $\mathrm{P}<0.0001)$ or subregion $(\mathrm{X} 2=29.2811 \mathrm{P}<0.0001)$ are related to the presence or absence of the disease [22]. The management practices within the herd, the production system, and the different iatrogenic practices such: dehorning, milking, vaccination [24], they can disperse viral particles in the herd and to promote the spread of the disease.

\section{Presence of Bovine Leukemia Virus in Milk Samples}

Milk samples are an important alternative for the diagnosis of EBL in dairy herds, as it can be taken quickly and without causing any stress in animals. The evaluation through the ELISA assay in milk allowed to establish a seroprevalence of $79.69 \%$ in Holstein cattle from specialized dairy herds in the department of
Antioquia [22], this seroprevalence is as high as others found in Argentine herds of $82.5 \%$ [25]. It has been reported that the milk of infected cows has exosomes that contain BLV proteins that although "are not infectious", are transmitted by an alternative route different from the viral infection and have an important role in the elimination of BLV proteins by the cells infected [26]. In addition, colostrum and colostrum replacers [27] are another vehicle for infection with BLV [12]. It has been found that colostrum can have cells infected with BLV; especially if the mothers are co-infected with the bovine immunodeficiency virus (BIV) [13].

\section{Bovine Leukemia and Immune System}

Bovine leukocyte antigen (BoLA) is membrane protein responsible for presenting antigenic peptides to lymphocytes and can alert on the presence of pathogens. The gene for this protein is highly polymorphic and has been associated with different diseases, because in some cases it could give resistance or susceptibility to the animal. 37 alleles for BoLA DRB 3.2 were identified in a population of 500 dairy Holstein cows specialized in the department of Antioquia (18). The most frequent alleles were BoLA DRB 3.2*16 (12.8\%), allele BoLA DRB 3.2*8 (16.3\%) and allele BoLA DRB $3.2 * 22$ (16.8\%). Two alleles associated with resistance against EBL were found: allele BoLA DRB 3.2*8 $(\mathrm{OR}=1.489, \mathrm{P}<0.05)$ and allele BoLA DRB $3.2 * 12(\mathrm{OR}=3.897$, $\mathrm{P}<0.10)$, while allele BoLA DRB $3.2 * 16(\mathrm{OR}=0.710, \mathrm{P}<0.10)$ was associated with susceptibility [28]. This information is of great importance for the producers since it is a beginning to develop selection plans, in which the animals are selected with the alleles of resistance or neutrality, thus avoiding the animals susceptible to this disease.

\section{Bovine Leucosis and Milk Production}

From a population of 500 dairy Holstein cows specialized in the department of Antioquia, the presence of BLV was related to productive and reproductive parameters. The BLV was significantly associated with the characteristics: milk production and kilograms of fat $(\mathrm{P}<0.05)$. No association was found between the BLV and the characteristics of kilograms of protein or somatic cell score $(\mathrm{P}>0.05)$. It was found that infected animals produce $7.67 \%$ less milk but produce more fat $(23.67 \mathrm{Kg} /$ lactation $)$ than healthy animals [19]. The compositional quality of the milk and the hygienic quality (measured as somatic cell score) are two very important factors for the payment of the milk and therefore the economic losses caused by this virus are significant in the dairy systems. For example, costs for secondary treatment of subclinical infections are \$6406 USD and annual costs for control and management of bovine leukemia are \$1765 USD [29].

\section{Control Measures}

There is no vaccine for this virus, the treatment for this disease is done through good practices with the use of needles, gloves or during milking; the discarding of infected animals also contributes to controlling the disease, in addition to continuing the research that generates more information about this patho- 
gen. From dairy herds can reduce the number of positive cases to BLV that occur. The positive effect has been observed when implementing rigorous management procedures, such as: using milk from negative cows or colostrum replacers to feed the calves, using milk from infected cows only after freezing or heating, using chemical dehorning or cauterization, using disposable needles for each animal and if they are not disposable, sterilize them among animals, clean and disinfect each implement used during tattoos, use separate gloves for rectal examination, wash and disinfect all equipment used in assisting the calves, use separate paddocks for infected cows of non-infected, implement a program against flies. "These practices reduce the spread of the disease as much as possible" [30].

\section{Conclusion}

Bovine leukemia is an important disease in the productive systems, as it silently affects the dairy herds, which leads to productive, reproductive and economic losses that involve not only small livestock, but also consumer health and food security of a region. It is important to continue the studies on the BLV and its effect on milk production systems, which will allow to expand the current panorama of this pathogen.

\section{Conflict of Interest}

This manuscript was prepared and reviewed with the participation of all the authors, who declare that they have no conflict of interest that compromise the validity of the results.

\section{References}

1. Baruta D, Ardoino S, Brandan J, Sosa R, Mariani E, et al. (2011) Leucosis Bovina Enzoótica. Ciencia Veterinaria 13(1): 9-14.

2. Dees C, Godfrey V, Schultz R, Travis C (1996) Wild type p53 reduces the size of tumors caused by bovine leukemia virus infected cell. Cancer Letter 101(1): 115-122.

3. Emanuelsson U, Scherling K, Pettersson H (1992) Relationships between herd bovine leukemia virus infection status and reproduction, disease incidence, and productivity in Swedish dairy herds. Prev Vet Med 12: 121-131.

4. Ott S, Johnson R, Wells S (2003) Association between bovine leukosis virus seroprevalence and herd level productivity on US dairy farms. Prev Vet Med 61(4): 249-262.

5. Kakinuma S, Maeda Y, Ohtsuka H, Konnai S, Oikawa M (2014) Bovine Leukemia virus titer and leukocyte population associated with mastitis in periparturient dairy cows. Intern J Appl Res Vet Med 12(3): 239-244.

6. Gillet N, Florins A, Boxus M, Burteau C, Nigro A, et al. (2007) Mechanisms of leukemogenesis induced by bovine leukemia virus: prospects for novel anti-retroviral therapies in human. Retrovirology 4(18): 1-32.

7. United States Department of Agriculture (2008) Bovine Leukosis Virus (BLV) on U.S. Dairy Operations.

8. Úsuga Monroy C, Echeverri J, López-Herrera H (2015) Molecular diagnosis of bovine leukemia virus in a population of Holstein cows, Colombia. Arch Zootec 64(248): 383-388.

9. Polat M, Takeshima S, Hosomichi K, Kim J, Miyasaka T, et al. (2016) A new genotype of bovine leukemia virus in South America identified by NGS-based whole genome sequencing and molecular evolutionary genetic analysis. Retrovirology 13(4): 1-23.

10. Divers T, Batrtholomew R, Gallingan D (1995) Evidence for transmission of bovine leukemia virus by rectal palpation in commercial dairy herd. Prev Vet Med 23: 133-141.
11. Darlington R, Digiacomo R, Evermann J (1985) Bovine leukemia virus transmission by dehorning in dairy heifers. Bovine Prac 19: 144-146.

12. Nagy D, Tyler W, Kleiboeker S (2007) Decreased periparturient transmission of bovine leukemia virus in calostrum-fed calves. Vet Intern Med 21: 1104-1107.

13. Meas S, Usui T, Ohashi K, Sugimoto C, Onuma M (2002) Vertical transmission of bovine leukemia virus and bovine immunodeficiency virus in dairy cattle herds. Vet Microbiol 84(3): 275-282.

14. Dus Santos J, Trono K, Lager I, Wigdorovitz A (2007) Development of a PCR to diagnose BLV genome in frozen semen samples. Veterinary Microbiology 119(1): 10-18.

15. Fechner H, Kurg A, Geue L, Blankestein P, Mewes G, et al. (1996) Evaluation of polymerase chain reaction (PCR) application in diagnosis of bovine leukaemia virus (BLV) infection in naturally infected cattle. Zentralbl Veterinarmed B 43(10): 621-630.

16. Rubianes A, Oriani D (2000) Reacción en cadena de la polimerasa (PCR) como herramienta diagnóstica de Leucosis enzoótica bovina. Ciencia Veterinaria Facultad de Ciencias Veterinarias pp. 103-109.

17. Rola M, Kuzmak J (2002) The detection of bovine leukemia virus proviral DNA by PCR-ELISA. Journal of Virological Methods 9(1-2): 3340.

18. Sandez N, Ilieva D, Sizov I, Rusenova N, Iliev E (2006) Prevalence of enzootic bovine leukosis in the Republic of Bulgaria in 1977-2004. Veterinarski arhiv 76(3): 263-268.

19. Úsuga-Monroy C, Zuluaga JJ, López-Herrera A (2018) Bovine leukemia virus decreases milk production and quality in Holstein cattle. Archivos de Zootecnia 67(258): 254-259.

20. Szewczuk M, Zych S, Katafiasz S (2012) Diagnosis of the bovine leukaemia virus infection in Polish Holstein-Friesian cowsand comparison of their milk productivity. Acta Vet Brno 81: 353-358.

21. Bojarojć-Nosowicz B, Kaczmarczyk E (2006) Somatic cell count and chemical composition of milk in naturally BLV-infected cows with different phenotypes of blood leukocyte acid phosphatase. Arch Tierz 49(1): 17-28.

22. Úsuga-Monroy C, Echeverri-Zuluaga J, López-Herrera A (2018) Molecular and serological detection of bovine leukemia virus in a population of Holstein cows, from Colombia. Revista Mexicana de Ciencias Pecuarias 9(2): 387-399.

23. Mariño O (1984) Situación de la investigación en leucosis bovina en Colombia. Revista ACOVEZ 8(27):22-26.

24. Ortega D, Sánchez A, Tobón J, Chaparro Y, Cortés S, et al. (2016) Seroprevalence and risk factors associated with bovine leukemia virus in Colombia. J Vet Med Anim Health 8(5): 35-43.

25. Felmer R, Zúñiga J, Recabal M (2006) Estudio comparativo de un PCR anidado, ELISA y AGID en la detección del virus de la leucosis bovina en muestras de suero, sangre y leche. Arch. Med. Vet 38(2): 137-141.

26. Yamada T, Shigemura H, Ishiguro N, Inoshima Y (2013) Cell Infectivity in Relation to Bovine Leukemia Virus gp51 and p24 in Bovine Milk Exosomes. PLosone 8(10): 1-7.

27. Choudhury B, Finnegan C, Phillips A, Horigan M, Pollard T, et al. (2015) Detection of Bovine Leukaemia Virus Antibodies and Proviral DNA in Colostrum Replacers. Transbound Emerg Dis 62(5): e60-e61.

28. Úsuga-Monroy C, Echeverri J, López-Herrera A (2016) Association between Genes BoLA-DRB3.2*8 and BoLA-DRB3.2*12 with Resistance and BoLA-DRB3.2*16 with Susceptibility to Infection by Bovine Leukemia Virus. Pakistan Veterinary Journal 36(4): 400-404.

29. Rhodes J, Pelzer K, Johnson Y (2003) Economic implications of bovine leukemia virus infection in mid-Atlantic dairy herds. J Am Vet Med Assoc 223(3): 346-352.

30. Evermann J (2014) Bovine Leukosis-Where have we been. Infection 2(3): 1-5. 


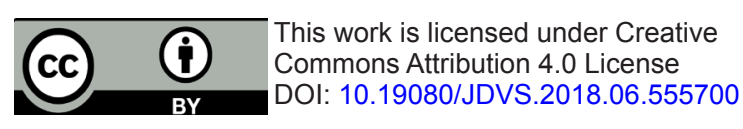

\author{
Your next submission with Juniper Publishers \\ will reach you the below assets \\ - Quality Editorial service \\ - Swift Peer Review \\ - Reprints availability \\ - E-prints Service \\ - Manuscript Podcast for convenient understanding \\ - Global attainment for your research \\ - Manuscript accessibility in different formats \\ ( Pdf, E-pub, Full Text, Audio) \\ - Unceasing customer service \\ Track the below URL for one-step submission \\ https://juniperpublishers.com/online-submission.php
}

